\title{
Nakil Sözleşmesi ve Nakliyecinin Sorumu
}

\author{
Doçent Dr. Hikmet BELBEZ
}

Kara nakliyatı iki kısma ayrılır: Eşya (TK m. 890-921) ve eşhas nakliyat (TK. m. 922-931). Bu yazıda kara yoluyla yaplan eşya nakliyatinda nakliyecinin sorumu gözden geçirilecektir.

\section{I}

Ticaret Kanunu - Borçlar Kanunu münasebeti.

1. Kara nakliyatı Ticaret Kanunumuzdan başka Borçlar Kanununda da tánzim edilmiştir (Bk. m. 431 vdd: nakliye mukaveleleri). Her iki taızim şekli arasında bir denklik ve uygunluk olsaydı, böyle aynı mesele hakkında muhtelif yerlerde hükümler bulunmasının mahzuru olmiyabilirdi. Fakat nakliyat hususunda her iki kanunun kabul etmiş olduğu esaslar ve koymuş olduğu hükümler arasında prensip ayrılıkları mevcuttur. Meselâ:

a) Borçlar Kanunumuz nakliye sözleşmesinin vekâlet bağıtının bir nevi olduğunu kabul" etmiştir (1). Ticaret Kanunumuzun nakliyata dit faslının kuruluşuna ve hükümlerinin mahiyetine göre ise — ileride yörüleceği gibi (2). - nakil sbzleşmesi daha ziyade istisna bağıtına yaklaşmıştır.

b) Borçlar Kanunumuza göre eşyanm, bilfarz zayi olması halinde nakliyeci bunun "....Müdebbir bir nakliyeci tarafından ittihaz olunacak tedbirler ile önüne geçilemiyecek hal ve vaziyetten..." doğduğunu ispat ederse sorumdan kurtulur (3). Ticaret Kanunumuza göre ise sorumdan kurtulabilmesi için bu ziyan'in, kanunun tadidî olarak saymış olduğu hallerden ileri geldiğini ispat etmesi lâzımdır (4).

(1) Borçlar Kanunu (BK) m. 431.

(2) Bak ileride S. 391.

(3) BK. m. 438.

(4) Bak ileride s. 392 . vdd, 
c) U̧̧̇üncü ve çok önemli bir fark da: Borçlar Kanunumuza göre nakliyecinin sorumu hakkındaki hükümler âmir hükümlerden değildir; nakliyeci sorumunu sözleşme ile daraltabilir, hattâ büsbütün ortadan kaldırabilir (5). Ticaret Kanunumuza göre ise, nakliyecinin "ademi mesuliyeti» hakkında sözleşmeye koyacağ̀ bütün hükümlet batıldir (6).

2. Ayrı ayrı kanunlarda yer almış ve bazı noktalarda birbirinden ayrılmakta olan bu hükümlerden hangileri uygulanacaktır? Yarg1tayın bu nokta hakkında bir kararma rastlayamadık. Tatbikatta mahkemelerimizde Ticaret Kanunundaki hükümler uygulanmaktadır. Ticaret Kanununun 20 inci maddesine göre nakliyat ticarî muamelelerdendir: Bı̀ itibarla bu husustaki ihtilâflar ticaret mahkemelerince çözülmekte ve Ticaret Kanunu da Borçlar Kanununa nazaran hususî bir kanun durumunda olduğundan, mahkemeler Borçlar Kanunundaki nakliyata müteallik hükümleri nazarı itibara almıyarak Ticaret Kanunundaki hükümleri uygulamaktadırlar. Bu itibarla biz de incelemcmize Ticaret Kanununun nakliyat hakkındaki hükümlerini esas tutacăgrz.

II

Nakil sözleşmesi.

I. Unsurları. Karada eşya nakli bir nakil sözleşmesine dayanılarak yapllır. Nakil sözleşmesini Ticaret Kanunumuz 887 inci maddesinde tarif etmiştir; buna göre nakil sözleşmesi «... bir nakliyecinin ücret inukabilinde eşyanın karada ve sularda nakillerini taahhüt eylemesi..." dir.

Bu tariften "nakliyeci» olmıyan bir kimsenin yapacağı nakliyatun răkil sözleşmesi şumulüne girmiyeceği zannı uyanabilir. Bunu önlemek içindir ki kanun bir sonraki maddesinde: «...nakliyeciliği kendisine san'at. ittihaz etmeyip eşya ...naklini ârızî olarak taahhüt eden kimse hakkında dahi bu fasıl ahkâmı tatbik olunur...) demiştir.

Şu hale göre nakil sözleşmesinden sorumlu tutulabilecek birbjrinden ayrı ü̧ şahıs grubu bahse konu oluyor:

1) Asıl nakliyeci. Yani nakliyeciliği kendisine mutad san'at edinmiş, ineslek ve meşgalesi nakliyecilik olan kimseler.

2) Mutad san'atları nakliyecilik olmamakla beraber ârızî olarak

(5) Oser-Schönenberger, Obligationenrecht. Kommentar zum Schweizerischen Zivilgesetzbuch, 2 nci basi, cilt V, m. 447 N. 3, s. 1631.

(6) Bak ileride s. $394 / 395$. 
muayyen bir nakil işini üzerine almış olan tacirler. Bunların asıl iştigal ettiklerì ticarî konular başkadır; eşya naklini arızî olarak deruhde etmişlerdir.

3) Nihayet ne nakliyeci ve ne de herhangi bir tacir olmadığı, yani hiçbir ticari sıfatı bulunmadı̆̆ı halde herhangi bir nakliye işini artzi olarak üzerine almıs olanlar.

Kanunun sarahati karşısında bunlarm hepsi hakkmnda Ticaret Kanununun nakliyecilik hakkında hükümleri uygulanacaktır. Bu tasnifin ancak şu bakımdan önemi olabilir: kanunun, nakliyecinin sorumu için koyduğu haller dışında sorumun bahse konu olması takdirinde ilk iki grup tacir olduklarından müdebbir ve basiretkâr bir tacir gibi hareket etmiş olmaları lâzım gelecek, bu bakımdan sorumları tacir olmıyanlara nazaran daha ağır olacaktır.

Buna göre herhangi bir kimse icabmda nakliyeci olarak bahse konu olabilir. Aşağıdaki şartlar da meveut olduğu takdirde, o kimse, sıfatına bakılmaksızm, Ticaret Kanununun nakliyat hakkkındaki hükümlerine bağlı tutulacaktır:

a) "Nakil", yani bir şeyin bir yerden başka bir yere taşınması. Bunda taşınacak olan mesafenin önemi yoktur. Bir șehirden diğer bir şehre taşıma halinde nakil bahse konu olacağı gibí, aynı şehir içinde, hattâ bir apartımanın bir katından diğer bir katına taşıma yapllmasi halinde de yine nakil meveuttur. (7).

recht und Schiffahrtsrecht; 4 üncü basi, s. 718.

Taşıma tarzının da önemi yoktur. O şeyi bir nakil vasıtası (=taşit) ile taşıyabileceği gibi hayvan kuvvetiyle de taşıyabilir (8); hattâ eşya kendi kuvvetiyle bile hareket edebilir; meselâ bir hayvanı, veya bir otomobili bix yerden diğer bir yere götürmek (9). Nakliyecinin nakil işini kendi vasıtasiyle yapması da şart değildir; başkalarma ait vasitalarla nakliyat yapması takdirinde de nakliye sözleşmesi bahse konudur. (10).

(7) Oser-Schönenberger, age., m. 440 N. 3, Julius von Gierke, Handelsrecht und Schiffahrstsrecht, 4. üncï basi, s. 718.

(8) Ritter. Kommentar zum Handelsbesetzbuch, 2 nci basi, S. 425 N. 3. s. 678. Hattâ taşumanın insan kuvveti ile yapılması halínde de nakliye sözleşme si bahse konudur; umumî olarak hayatta hamallara nakliyeci gözüyle bakılmaması bu esasda hiçbir değişiklik yapmaz; olsa olsa hamallar, örf ve teamül icabi olarak, kendilerine bir nakliye senedi verilmesini istiyemiyeceklerdir. Krş. Ritter, age., \$ 425 N. 3, s. 687: Gierke, age., s. 718.

(9) Ritter, age., \& 425 No. 5 b, 687; von Gierke age., s. 718; Oster-Schönenberger, age., m. 440 No. 4.

(10) Oser-Sthönenber ker, age., m. 440 N. 4. s. 1609. Staub, Kommentar

Hukuk Faküitesi Mecmuası: 11 
b) Taşımanın konusu "eşya» olacaktır. Burada eşyadan maksat yeri değiştirilebilen her 'türlü mallardır; elverir ki cisim halinde bulunsunlar, yani maddî bir varlıkları olsun (11). Haber nakli, nakil sözleşmesi dışında kalır. Buna mukabil canlı hayvanlar da "mal" dan sayılır.

c) Nakliyeci taşıma işini "deruhde" edecek, yani bu işi üzerine alacaktır. Eşya tamamiyle kendi nezareti ve muhafazası altına girecektir. (13) Ticaret Kanunu sadece "taahhüt" tabirini kullanyor ki kanaatımızca, bu zayıf bir ifadedir.

d) Nakliyat bir ücret karşılı̆̆nda yapılacaktır. Bu çok esash bir unsurdur. Ưcret bahse konu olmazsa, ortada bir nakil sözleşmesi de mevcut değildir (14).

2. Tarafları. Nakil sözleşmesinin taraflarından birì nakliyeci, diğeri de mürsil $=$ gönderendir. Bir de mürsel-ün-ileyh vardır ki, o da eşyaların kendisine gönderildiği kimsedir. Gönderen ile gönderilen aynı kimse olabilirler. Bunlar başka başka kimseler olsalar bile gönderilen nakil sözleşmesinin taraflarından değildir (15).

Fakat gönderilen sözleşmede doğrudan doğruya taraf olmamakla beraber sözleşmenin alâkalıIarındandır ve belli bir andan itibaren gönderenin hakları kendisine geçer ve mallar üzerinde de tasarruf, icabında da nakliyeciyi dava etmek hakkını elde eder. Zira her nakil sözleşmesi aynı zamanda üçüncü kişi, yani gönderilen lehine yapılmıß̧ bir sözleşmedir (16).

3) Şekil ve mahiyeti. Nakil sözleşmesinin mahiyetinin anlaşılması ve tesbiti önemlidir. Çünkü nakliyecinin sorumuna taallâk eden birçok esaslar bundan çlkmakta ve sorumu sebebleri bu sayede anlaşılmaktadır.

Nakil sözleşmesi hiçbir şekle bağlı değildir. Bunu Ticaret Kanununun 890 incı maddesi açık olarak ifade etmiştir. Sözleşme «... ta-

zum Handelssgesetzbuch, 12 ve üçüncü bası. § 425 N. 2, N. 8, Ritter. age., § 425 No. 5 b, s. 687; Düringer-Hacherburg-Bing. Hardelsegestzbuch, cilt V; kısım 2, 3, üncü bası, $\$ 425$ No. 6. s, 1137.

(11) Ritter, age., \&. 425 No. 5 a, s. 687; Oser-Schönenber ger, age., m. 440 No. 6

(12) Von Gierke, age., s. 718; Oser-Schönenberger ,age., m. 440 N. 8.

(13) Oser - Schönenberger, age., m. 440 N. 12; von Gierke, age., s. 718.

(14) Fitter, age., § 425 No. 7 a, s. 688.

(15) Von Gierke, age., s. 718.

(16) Oser - Schörenberger, age, m. 443 N. 16; von Tuhr-Siegwart, Allgemeiner Teil des Schweizerişchen Obligationenrechts, cilt II, 1944, s. 686; von Gierke, age., s. 718; Staub, age., \$425 N: 15. s. 881 . 
rafların rıza ve muvaffakatları ve eşyanın nakliyeciye teslimi.... in tamam olur.

Gırçi nakliyeci isterse gönderen kendisine iki nüsha olarak bir nakliye senedi vermeğe mecburdur.. Fakat nakliye senedi ile nakil sözleşmesini asla birbirine karıştırmamalıdır. Nakliye senedi tanzim olunmasa dahi bağıt tamamdir (17).

Nakil sözleşmesinin mahiyeti hakkmda çeşitli görüşler ileri sürülmektedir:

a) Bunlardan birincisi nakil sözleşmesinin mahiyeti itibariyle bir hizmet akdi olduğudur. İk bakışta akla yakın gelen bu telâkkide hiç isabet yoktur. Nakliyeden maksat bir hizmetin görẗilmesi değil, belli' bir sonucun elde edilmesi, bir şeyin bir yerden diğer bir yere götürülmesidir.

b) İkinci bir görüşe göre, nakliye sözleşmesi mahiyeti itibariyle birvekâlet bağıtıdır. Bu telâkki İsviçrede de hâkimdir. (18). Nitekim Borçlar Kanunumuzun 431 inci maddesinin II inci fıkrasında "...atideki hükümler mahfuz kalmak üzere vekâlet kaideleri nakil mukavelesi için de tatbik olunur...” denmektedir.

c) Bizim de iştìâk ettiğimiz hâkịm telâkkiye göre iṣe (19) nakil sözleşmesi mahiyeti itibariyle bir istisna bağıtıdur. Çünkü nakil sözleşmessinin konusu ne hizmet akdinde olduğu gibi muayyen veya gayri muayyen bir zamanda "bir hizmet görmek", ne de vekâlette olduğu.gibi "tahmil olunan bir işin idaresi veya tekabbül edilen hizmetin ifası" değildir. Nakil sözleşmesinin hedefi, belli bazı eşyanın bir yerden diğerine taşınması, o şeylerin tam ve sağlam olarak ve vaktinde varma yerine ulaştırılmış olması, yani muayyen bir eser meydana getirilmesi, muayyen bir sonucun elde edilmesidir.

Diğer taraftan ücret vekâlet bağıtının zarurî bir unsuru değildir. Hattâ asıl olan, vekâletin ücretsiz oluşudur; ücret istisnadır(20).

(17) Nakliye senedi nàma yazılı oldukça alelade bir ispat belgesidir. Fakat emre veya hamiline yazili olan nakliye senetleri - Alman hukukunun aksine olarak (krş. Curt Bühland, Frachteschäfte, Rechtsvergleichendes Handwörterbuch für Zivil-und Handelsrecht, cilt II, s. 520) - bizde emteayı temsil eden birer senet mahiyetindedir. Bu çeşit nakliye senetlerinin ciro veya tesJiminin eşyanın mülkiyetini nakledeceği Ticaret Kanununun 894. üncï maddesinđe açık olarak yazılıdur.

(18) Oser-Schönenberger, age., m. 440 N. 20 vbb.

(19) Ritter. age., § 425 No. 7b, s. 688; Staub, age., \& 425 N. 1, s, 875; Dïringer-Hachenburg-Bing, age., Nakil sözleşmesi hakkinda ilk mülahazalar No. 3, s. 1131.

(20) Krş. BK. m. 356. 
Nakil sözleşmesinde ise, 1stısna bağıtında olduğu gibi, ücret sözleşmenin zarurì unsurlarındandir (21).

Vekâlet bağıtında vekilin ữzerine aldığı işi bizzat yapmaș assldır, başkalarına yaptırması istisnadır. Ancak hususî bir sözleşme ile vekile mezuniyet verilmiş olur veya halin hususî şartları icabettirirse başkasmı tevkil edebilir. Nakil sözleşmesinde ise -bütün istisna bağıtlarında olduğu gibi (22) - işi bizzat yapabileceği gibi kendi idaresi altında yaptırabilir ve hattâ büsbütün başkalarına da gördürebilir. Bunun için ayrıca izin ve yetki almasina lüzum yoktur.

Böyle olduğu halde nakliyeci işi kendilerine havale ettiği başka nakliyecilerin fiil ve hareketlerinden, tıpkı kendi fiil ve hareketinden olduğı gibi, sorumludur. Vekil ise, bir başkasın tevkile yetkili olduğu takdirde, yalnız yetkisini kullanırken ve talimat verirken tekayyüd ve ihtimam göstermekle mükelleftir; yani yalnı seçimdeki kusurundan sorumludtur. (23).

Yine çok önemli bir nokta da, hizmet bağıtı ve ücretli vekâlet bağıtlarında, beklenen sonuç elde edilsin veya edilmesin, sarfedilen emek için ücret istemek müstahdem ve vekilin haklarıdır. Halbuki nakil sözleşmesinde gaye sonuç, eserdir. $O$ elde edilmedikçe ve meselâ mallar hedeflerine ulaşmadıkça nakliyeciye hiçbir ücret verilmez.

$\mathrm{Bu}$ izahat gösteriyor ki doğru olan istisna bağttı telâkkisidir. İsviçrede de, müş̧erek hukukun (pandekt hukukunun) tesiri sonucu olarak. bu görüş hakimdi. Sonradan vekâlet bağıtı esasına dönülmüş olmasumn sebebini bizce tesbit etmek maalesef mümkün olamamıştır. Şurası muhakkaktır ki nakil sözleşmesini vekâlet bağıtına benzetmek için İsviçre kanun koyucusu bir dereceye kadar zor kullanmıştıi; nitekim vekâlet hükümlerinin cari olacağını bir madde ile tasrih etmek mecbudiyetini duymuştur. (IBK. m. 44; TBK. m. 431).

Ticaret Kanunumuzda hâkim olan görüşün istisna bağıtı telâkkisi olduğunu tereddütsüz olarak söyliyebiliriz.

\section{III}

Nakliyecinin sorumu.

1. Sorum halleri. Nakliyeci teslim aldığı andan teslim edeceği ana kadar geçen zaman içinde eşyanın ziyar veya hasarından veya

(21) Bak, yưkarıda s. 390 ve orada dipnot 14 .

(22) BK. m. 356.

(23) BK. m. 391 . 
geç olarak tesliminden doğacak zararlardan sorụmludur. Bütün bu hallerde zararın nakliyecinin kusurundan ileri geldiği farzolunur. Sorumdan kurtulabilmesi için, kanunun çizdiği sınurlar içerisinde, - zıya, hasar veya gecikmenin kendi kusur ve hatasindan ileri gelmediğini ispat etmesi lâzımdur (24). Şu halde kanunumuz kusur kuramını Şahap Arıç, Yargitiy İçtihatlarına göre haşiyeli Ticaret Kanunu, 1946, No. 792. kabul etmiş, ancak ispat külfetini çevirerek bunu nakliyeciye yüklemiştir. (24a) .

$\mathrm{Bu}$ hale göre zıya, hasar veya gecikmeden doğacak zararlar yüzünden açılacak tazminat davasında beyyine külfeti iki taraflıdır:

a) Evvelemirde gönderen (veya gönderilen) nakliyeciye tam ve ayıpsız olarak teslim edilen eşyanın hedefine varmadığını veya bozuk yahut eksik bir halde vardığını veyahut da belli müddetten sonra geldiklerini ispat edecektir. Bunu ispat ederse artik ziya, hasar veya gecikmeye nakliyecinin sebebiyet verdiğini, bunlarm onun kusur ve hatasindan ileri geldiğini de ayrica ispat etmesine hacet yoktur.

b) Bundan sonra ispat yükü artık nakliyeciye geçmiştir. Nakliyeci kendisini ibraya çalışacak, sorumdan kurtulabilmek için ziya, hasar veya gecikmenin kendi kusurundan değil, kanunda yazılı hallerden ileri gelmiş olduğunu ispat edecektir.

Bu haller nelerdir? Bunları Ticaret Kanunumuzun ziya, ve hasar için $9 \breve{g} 4$ ve gecikme için de 903 üncü maddesinde saymıştır.

$\mathrm{Bu}$ maddelerin hükümlerine göre naklíyeci sorumdan kurtulabilmek için ziya, veya hasarın:

1) Kendi hatasının sonucu olmtyan bir fevkalàde hal veya mücbir scbepten, (24b) yahut

2) gönderen veya gönderilenin fiilinden veya verdikleri emir ve talimatin uygulanmasindan, veyahut da

3) eşyada zaten mevcut olan noksan ve ayıplardan yahut eşyanın mahiyetinden veya ambalâjın fena yapilmasından, ileri geldiğini isbat etmesi lâzımdur.

Dikkat edilecek bir nokta (1). inci halde nakliyecinin yalnuz mucbir sebeb veya fevkalâde halin vukuunu değil, aynı zamanda

(24) Yargitay Ticaret Dainesi Karan (YTDK.) 562-25. 3. 1943; krş.

Şahap ARIÇ, Yargitay içtihatlarina göre haşiyeli Ticaret Kanunu, 1946, No. 792.

(24a) E Hirs. Ticaret Hukuku Dersleri, 1946, No. 665, s. 658.

(24b) Mücbir sebep ve fevkalâde hal için bak. E Hirş, age,. No. 663, 666 ve bilhassa $A$ Gözübïyö̈k, Sözleşmelerin feshi ve tadili bakımından Mücbirsebepler ve beklenmiyen haller, 1945. 
bunların kendi kusurundan ileri gelmediğini de isbat etmek mecburiyetinde olmasıdır (25). Fevkalâde hal veya mücbir sebebin vukuuna kendisi sebebiyet vermiş olursa sorumdan yine kurtulamaz.

Gecikmeden doğan sorumda durum aşağg yukarı aynıdır. Burada nakliyecinin sorumdan kurtulabilmesi için gecikmenin ya:

1) bir mücbir sebep veya fevkalâde halden, veya

2) gönderenin veya gönderilenin filllerinden ileri geldiğini ispat etmesi lâzımdır.

Ticaret Kanunumuz bu noktada - Alman ve Anglo-Sakson (26) hukukunun aksine olarak ve Fransiz hukukuna yaklaşmak suretiyle (27). - nakliyecinin sorumdan kurtulabileceği halleri tahdidt bir şekilde (28) saymıştır. Alman hukukunda nakliyeci zararı doğuran zyya, hasar veya gecikmenin iyi ve müdebbir bir nakliyecinin vazifesinde göstereceği dikkat ve ihtimam ile bertaraf edilmiyecek hal ve şartlarda doğduğunu ispat ederse, sorumdan kurtulur (29). Kanunumuz böyle umumî bir kaide kabul etmemiş, nakliyecinin sorumdan kurtulabileceği halleri sıralamıştır. Bu haller dışında iyi ve müdebbir bir nakliyeci gibi özenmesine rağmen, ziya, veya hasar vukua gelir veya mallar gecikirse, yine sorumlu olur.

Şu var ki, tatbikaatta bu farkın okadar büyük bir önemi yoktur. Nakliyecinin bütün özeninin sarfına rağmen ziya, hasar veya gecikme vukuuna sebebiyet veren haller hemen hemen daima fevkalâde haller veya mücbir sebeplerdir.

2. Âmir hukuk. Şimdi Kanunumuzun çok dikkate değer bir hükmüne geliyoruz: Kanunumuzun nakliyecinin sorumu hakkında koymuş olduğu hükümler âmir hükümlerdir. Gerek Anglo-Sakson (30) ve gerek sair kontinental hukukun ve meselâ Alman (31) ve Fransız hukukunun aksine olarak, nakliyecinin bu sorumu sözleşme ile kaldirılamıyacağı gibi daraltılamaz da.

(25) YTDK. 2360-17.10.1946; krș. Atıç, age., No. 790.

(26) Krş. Curt Rühland, age., s. 531/532.; Halsbury's Laws of England, 2. nci bast, cilt 4 (Lord Hailshaw), No. 16, 17 vdd., s. 12 vdd.

(27) Fransiz TK. m. 97-99, 103, 104, 107. Fr. MK. m. 1784, 1148. Bk.

Curt Rühland, age., s. 529., Lyon Caên-Rengutt. Traité de Droit Commercial 5 inci bast, cilt III, No. 593 vdd.

(28) YTDK. 716-10.3.1942; krş. Arı̧̧, age., No. 791.

(29) Alman TK. \& 429.

(30) Schewcross-Beaumont, Air Law, 1945, No. 300, 301, s. 150;Mc Nair, The Law of the Air, 1932, s. 116; Curt Rühtand, age, s, 532 ve bilhassa Halsbury, age., No, 37 vdd, s. 27 vdd.

(31) Ritter, age., $\$ 429$ No. 6 , s. 701. 
Kanun gerek ziya ve hasar ve gerek gecikme halleri için ayri ayrı ve gayet açık olarak (nakliyecinin ademi mes'uliyeti hakkında mukaveleye derc olunacak ahkâm keenlemyekûndur» ve "adem-i mesuliyete dair şerait batıldır» demiştir.

Kanun filhakika yalnuz "adem-i mesuliyetten» bahsediyor. Fakat buna sorumun büsbütün kaldırılmasından başka tahdidi, daraltilması hali de girer. Çünkü daraltmağa müsaade edilecek olsa sıfur haddine kadar daraltmak da kabildir. Bunun içindir ki adem-i mesuliyete dair olan kayıtların mesuiliyetin büsbütün kaldırlması hallerinden başka mesuliyetin daraltılması halerini de içine aldığını kabul etmek lâzımdır.

Kanun koyucumuz bu bakımdan cidden tebrike değer. Böyle gayet ilerì ve sosyal bir fikri kanun şekline dökmüştür. Diğer avrupa devletlerinde nakliyecilik sahasında da geniş bir bağıt yapma serbetliği cari olduğundan, nakliyeciler çok kere birleşerek fiili inhisarlar kuruyor, halka istedikeri şartları kabul ettìriyorlar (32). Kanun koyucuları da karışmadıkları için mahkemeler bununla mücadele halindedir; Fili inhisar vaziyeti var midır, yok mudur? buna göre nakliyeciler tarafından zorla kabul ettirilen umumî şartlar batıl midır, meseleleri bütün mahkemeleri meşgul etmektedir.

3. Sorum hadleri. Ziya, hasar ve gecikme hallerinde nakliyecinin ne zaman sorunmlu olacağını gördük. Şimdi bu sorumun derecesini gözden geçirelim. Bütün bu hallerde nakliyeci ne dereceye kadar, ne miktarda sorumludur?

Kanunumuzun bu husustaki hükümleri çok karışı ve anlaşılması güçtür. Her üç hale mahsus olan hükümleri ayrı ayrı gözden geçirelim:

a) Ziya! 908. jnçi maddenin I inci flkrasına göre ziyadan doğan zarar

1) nakliye senedine yazılmıs olan kıymete; nakliye senedinde bir kıymet gösterilmemişse,

2) Aynı cins ve vasıftaki eşyanm teslim mahallinde teslim zamanındaki kıymetine göre tâyin oalunur.

Ziyadan maksat yalnız fiilen ve maddeten kayıp olmak değil, aynı zamanda o malın gönderilene teslim edilememesi halidir (33). $\mathrm{Bu}$ hal neden ileri gelirse gelsin, netice değişmez; buun sebebi mad-

(32) Von Gierke, age., s. 723 vdd.; Düringer-Hachenburg, age., $\$ 430$ N. 27, s. 1192; Staub; age., $\$ 429$ N. 17, s. 893; Cosack, Lehrobuch des Handelsrechts, 9. uncu bas1, s. 317

(33) Ritter, age, $\$ 414$ No. 2. s. 653 . 
dî ve fiili bir imkânsızlık olabileceği gibi hukukî bir sebep te ilabilir. Eşyanın tamamının değil de bir kısmını zayi olması halinde kismî ziya bahse konu olur ki meselâ eksilme kısmî ziya demektir (34).

b) Hasar. Yine ayni maddenin II inci flkrasına göre hasardan doğan zarar, eşyanın teslim edileceği yerde hasardan önceki kıymeti ile hasardan sonraki kıymeti arasındaki farka göre hesap edilir.

Hasardan maksat da malın vasiflarında vukua gelecek her türlü bozulna ve değişmedir (35).

Gerek ziya ve gerek hasar halinde malin varma yerinde ve varma zamanındaki kıymeti âzamî tazminat haddidir (36). Zarara uğrıyan taraf, meseslâ gönderilen, kendi sübjektif menfaatini ileri süremez. knymet objektif esaslara göre tâyin ve tesbit olunur.

Karunumuz 908 inci maddesinde ziya ve hasar halleri için tazminat hadlerini bu şekilde tesbit ettikten sonra 909 uncu maddesinde aynı hallerden yenide bahsetmiştir. Bu madde de ayen șöyle yazulidir:

(Eşyanın ziyaı veya bozulması halinde nakliyeci kendisine beyan ve tarafından kabul edilmiş olan kıymetleri tazmin eder. Yolcuları mahiyet ve kiymetlerini beyan etmiyerek nakliyeciye tevdi ettikleri eşyanın ziyaindan mütevellit zarar...) şu şekilde tesbit olunur.

İște bu maddenin vücudunun hikmetini anlamak kolay değildir. Bir önceki maddede ziya ve hasardan doğan zarar ve ziyan meselesi halledilmişken burada tekrar karşımıza çıkıyor.

Acaba evvelki madde ile zarar ve ziyanın nasil hesaplanacağr. getirilmek, bu madde ile ise bu zararı tazmin mükellefiyeti mi konmak istenmiştir?.

Yoksa bu maddede "yolculardan" da bahsedildiğine göre, yolcu eşyasına taallûk eden bir madde midir? Bu takdirde yerini şaşırmış bir mäddedir demektir. Çünkü yolcu naklinden kanunun ayrı bir kısmıda bahsedilmiş ve orada bu meseleler yine maddelere atıf yapllmak suretiyle çözülmüşsür.

En uygun izah tarzl, evvelki maddede bir nakliye senedi tanzim edilmiş olduğu hallerin nazar-1 itibara alınmış olmasına mukabil, burada nakliye senedi kesilmemiş olması halinin gözönünde tutulmuş

(34) Ritter, age., \$ 414. No. 2, s. 653-654.

(35) Ritter, age., \& 414, No. \$, s. 654.

(36) 37.6 sayilı Posta Kanununa göre (m. 35) posta idaresi, ziyaa ŭg ratılan kıynetlì paket ve mektuplarm hakikî kıymetlerini tazmin ile mükellef olup sorumu hiçbir zaman bu kıymeti geçemez. 
olmasıdur. Fakat, evvelki maddede nakliye senedine yaztlmış olan kıymetin nazar-1 itibara alınacağı yalnız ziya halinden bahseden I inci flkrada yazllıdır. Hasar halinden bahseden II ici fikrada bu kayıt da yoktur. Sonra nakliye senedi tanzim edilmiş olan hal ile tanzim edilmemiş olduğu hal arasında böyle bir fark yapılmasinın lüzumunu izah ta pek kolay değildir. Çünkü hukuken ikisi arasında hiçbir fark yoktur. Esasen nakliye senedi tanzimi, nakil sözleşmesinin tekemmül etmesi için şart da değildir.

Bu maddenin așıl önemi kiymetli eşya, para, kıymetli evrak vs. den dolayı olan sorumdan bahsetmesindedir.

c) Gecikme. Eşyanm söleşme vey̧a ticarî örf ile belli olan ve bun. ların bulunmaması takdirinde halin icaplarına göre makul ve mutedil görülen bir zaman içinde taşınması lâzımdır. Taşınmazsa nakliyeci sorumlu olur. Sorumun derecesini de Kanunumuz şu şekilde tesbit etmiştir:

Eşya yukarıda söylenen müddetlerden sonra varırsa, nakliye ücreti geciken müddet ile mütenasip olarak indirilir.

Fakat şayet gecikme müddeti söleşme ile belli olan müddetin iki mislini geçerse, nakliyecinin ücreti hiç verilmiyeceği gibi nakliyeci bu yüzden ileri geldiği spat olunan zarar ve zyanla da sorumlu olur.

Mallar büsbütün kayıp olursa, nakliyeci yalnız kıymetlerini ödemek zorunda kaldığı halde teslim müiddeti iki mislini geçer, fakat mallar neticede yine vasıl olursa bütün zarardan sorumlu oluyor. Bütün zarara mahrum kalınan kâr da dahildir. Binaenaleyh ortada bir nisbetsilik vardır.

4. Sirumun istisnalarn. Nakliyecinin sorumu hakkindaki bu ana kaidelerin bazı istisnaları vardır:

a) Eğer nakliyeciye mahiyetleri icabı olarak nakilleri sirasında hacım ve vezinleri azalan, meselâ akmtı ve sızıntr yapan mal verilirse, nakliyeci bu husustaki sorumunu belli bir miktar üzerinden peşin olarak tahdid edebilir (TK. m. 906).

b) Kıymetli eşya, sanat eserleri, para ve kiymetli evrakm ziya ve hasarindan ancak bunlarm bu mahiyetlerinin teslim sirasinda kendisine bildirilmiş olmasi halinde sorumlu olur. Şukadar ki bunların kıymetlerinin bildirilmesine hacet yoktur; sadece kıymetli eşyadan . olduklarm bildirmek yeter. Bu takdirde sonradan klymetlerini ispat etmek gösteren veya gösterilene düşer. Nakliyeciye kıymetli eşyadan oldukları yolunda yapılan beyanla nakliyatın hususî rizikosu kendisine hatırlatılmış olur. Beyan edilmezse sözlemşeden doğan hiçbir hak ileri sürülemez (TK m. 909 II). 
c) Bütün bu hallerde eğer nakliyecinin hiyle veya fahiş kusurt butunursa, ararm tamamindan sorumlu olur (TK. m. 909 II). Tam zarara mahrum kalınan kâr da girer.

\section{Başkalarının kusurundan dolayı sorum.}

1. Genel olarak. Bu suretle nakliye bahsinin en önemli bir meselesine gelmiş oluyoruz:

Yúkarıda nakil sözleşmesinin mahiyet itibariyle bir istisna bağıtı olduğunu söylemiştik. Bunun icabı olarak nakliyeci nakliyatı bizzat yapabilir, veya kendi idaresi altında başkalarına da yaptırabilir, yahut nakil işini tamamiyle başkalarına bırakabilir. Bu takdirde ise yardıncı olarak kullandığ bütün bu kimselerin kusurlarından ve sebebiyet verdikleri zararlardan sorumlu olur. Bu esas Ticaret Kanunumuzun 907 .inci maddesinde şu suretle ifade edilmiştir:

«Nakliyeci, kendi makamına kaim olan bütün nakliyecilerin, kendisine muavenet edenlerin, yahut eşyantn naklini kendilerine tevdi ettiği kimselerin nakleden eşyanın mürselünileyhe teslimine kadar vuku bulan fiil ve hatalarindan mesuldürn.

Umumî olarak nakliyati yaparken nakliyeciye iki sınıf insan yardım edebilir:

1) Birinci sınıf serbest iş ve meslek sahibi, yani patron ve müteşebbis mevkiinde olmayp, nakliyeciye bir iş veya hizmet münasebeti ile bağlı bulunan kimseler. Bunlar da ya

a) Kendi daimî müstahdemleri, yani doğrudan doğruya onun maiyetinde bulunanlar, veya

b) daimî müstahdemlerinden olmayıp muayyen bir nakliyatta geçici olarak çaıştirıldığı kimseler olabilir. Meselâ hamallar, dışarıdan tuttuğu bir arabacı gibi.

2) Ikinci stn $f$ kimselere gelince: bunlar da nakliyecinin serbest meslek sahibi olan, mustakil çalışan yardumcllarıdır ki bilhassa başka nakliyeciler bahse konudur.

Burada da muhtelif haler bahse konu olabilir:

a) Mustakil kusmî nakliyeciler.

Gönderen muhtelif nakliyecilerle ayrı ayrı sözleşmeler yapar.

Bunlardan herbiri mustakil olarak yolun bir kısmı için eşyayı nakletmeği üzerlerine alırlar. Bu takdirde bu nakliyecilerden herbiri yolun yalnız o kısmı için sorumlu olur ve bunların sorumu yalnız gönderene (veya gönderilene) karşıdır. Nakliyecilerin kendi aralarında hiç münasebet ve ilgileri yoktur. Âkit ve muhataplan doğrudan doğruya gönderendir. 
b) Mustakil olmiyan kusmî nakliyeciler.

$\mathrm{Bu}$ da bir nakliyecinin bütün mesafe, yani eşyanın taşınacağı mesafenin tamamı için nakliyatı üerine alması ve kendiliğginden yardımei nakliyeciler kullanmasi halinde bahse konu olur. Gönderen sözleşmeyi yalnız bir nakliyeci ile yapar. Bu nakliyeci de diğer bir nakliyeciyi muavin olarak kullanır ve mesafenin muayyen bir kısmı için nakil işini ona gördürür. Bu sonuncu ile gönderen arasında akdi hiçbir münasebet yoktur .(37).

c) Müteselsil nakliyeciler.

Nihayet, mesafenin tamamı için birbirini takip eden muhtelif nakliyecilerle sözleşme yaplabilir. Gönderen birinci nakliyeci ile sözleşmeyi bütün mesafe için yapar ve ona bir nakliye senedi verir. Fakat bu nakliyeci nakliyat işini mesafenin yalnız bir kisminda bizzat icra eder ve müteakip mesafe için eşyayı senetle birlikte bir başka nakliyeciye devreder; o da kendisinden sonra gelen bir nakliyeciye devreder... ve ilâh...; müteakip nakliyecilerden herbiri nakliyata devam eder, Fakat gönderene karşı nakil sözleşmesine yalnız kendi mesafesi için değil, mesafenin tamamı için girmiş olur. Yani rakliyecierden herbiri mesafenin tamamindan sorumludur.

2. Ticaret Kanunumuza göre durum.

Şimdi Kanunumuzun 907. inci maddesini ele alarak saydığımız bu hallerin karşılığını bulmağa çalışalım:

Serbest çalışmıyan ve nakliyeciye bir iş ve hizmet bağıtı ile bağlı bulụnan yardumcllar; bunu Kanunumuzun akendisine muavenet edenler" ibaresi karşlamaktadır ve buna gerek daim $\hat{\imath}$ müstahdemleri. gerek arızî olarak çalıştırdığı yardımcıları girer.

Geçici olarak çalıştırdı̆̆ı kimseler tarafından yapılan zararlardan BK. 100 dairesinde, yani işlerini icra esnašnda ika ettikleri zarardan mesuldür. Bahse konu olan iş nakliyat olduğuna göre, doğrudan doğruya nakil işini icra esnasında ika ettikleri zararlardan sorumlu olacak, bunun dışında kalanlardan ise sorumlu olmıyacaktır.

Daimî müstahdemlerine gelince: Alman nazariye ve tatbikatı bunların verdikleri zararlardan olan sorumu çok genişleştirmiştir. Alman Ticaret Kanunu bizdeki gibi «kendisine muavenet edenler" demiyor, «kendi adamları» tabirini kullantyor. Bu ifade gözönünde tutularak nakliyecinịn doğrudan doğruya nakil işine istirak etmiyen ve meselâ eşya ile doğrudan doğruya temasa gelmiyen adamla-

(37) Bu hal kiracinun kiracılarmun durumunu hatırlatmaktadr. 
rının, bilfarz bir kâtip veya daktilosunun ika ettiği zarardan dahi sorumlu olacağı kabul edilmektedir (38).

Kanaatımızca bizde nakliyecinin sorumunu bu derece genişletmeğe imkân yoktur. Kanun "kendisine muavenet edenler" diyor. Binaenaleyh nakliyeci ancak muavin şahısların işlerini icra esnasında ika ettikleri zararardan, yani BK. 100 dairesinde sorumlu olur.

Serbest iş sahibi olan yardmmclarına, yani kendisine yardm eden diğer nakliyecilere gelince:

a) Mustakil Kusmî nakliyeciler. Kanun bunlarđan ayrica bahsetmemiştir. Bunlar doğrudan doğruya gönderen ile sözleşme yaparlar ve her biri yalnız kendi mesafesinden mesuldür. Yani doğrudan doğruya münferit bir nakliyeci gibi muamele görürler.

Bu nakliyecilerle doğrudan doğruya gönderen sözleşme yapabileceği gibi, nakliyecilerden biri de gönderenin vekili sıfatiyle ve gönderen nam ve hesabına da sözleşme yapabilir. Bu takdirde o nakliyeci gönderene karşı, tıpkı bir vekil gibi, sözleşmedeki kusurundan sorumlu olur.

Nakliyecilerden birinin gönderen hesabına, fakat kendi namına sözleşme yapması da mümkündür. Bu takdirde nakliyeci bir nakliye komisyoncusu gibi mes'ul olur.

b) Muavin şahıs vaziyetinde bulunan kısmî nakliyeciler: bunları da maddemizin "eşyanın naklini kendilerine tevdi ettiği kimseler» ifadesi karşıllyor. Gönderen yalnız birinci nakliyeci ile sözleşme yapar. Kendi âkidi yalnız birinci nakliyecidir ve gönderenè karşı yalnız birinci nakliyeci ve mesafenin tamamı için sorumludur. Diğer nakliyecilerin fiilinden BK. 100. dairesinde muavin şahısların sorumunda olduğu gibi sorumludur.

c) Müteselsil nakliyecilik haline gelince: Bunu da bir dereceye kadar maddemizin "kendi makamma kaim olan bütün nakliyeciler" ifadesi karşllyor. Birinci nakliyeciden sonra gelen nakliyeciler nakliye senedi hükümleri dairesinde nakil sözleşmesine dahil olarak gönderene karşı âkit mevkiine girer ve sorumlu olurlar. Fakat bununla birinci nakliyeci sorumdan kurtulmuş olmaz. $O$ yine bütün nakliysttan ve kendisinden sonra gelen bütün nakliyecilerin fiil ve hareketlerinden sorumlu kalır.

Öteki nakliyecilere gelince: Müteselsil nakliyeciliğin yukardaki tarifine göre aradaki nakliyecilerin her birinin gerek kendisinden

(38) Alman Temyiz Mahkemesi (RG.) 7 s. 127,57 s. 128.104 s. 151; kґş. Ritter, age., \& 431 No. 3. 704; Düringer-Hachenburk, age, $\$ 431$ N. 4, s. 1194; Staub, age., \& 431 N. 2, s. 905. 
sonra gelen ve gerek kendisinden evvel gelmiş olan nakliyecilerin fiillerinden sorumlu olması lâzım gelirdi. Fakat kanunumuz bu umưnî kaideden ayrılmıştır. 910 uncu maddede: "birinci nakliyeciden sonra gelen nakliyeciler nakil olunacak eşyayı ve nakliye senedini tesellüm ettikten sonra tevellüt eden bütün borçlarda evvelki nakliyeci makamına kaim olurlar» deniyor. Buna göre, sonraki nakliyeciler, eşyayı ve nakliye seneđini tesellümden evvel doğmuş olan borçlarda evvelki nakkliyeciler yerine geçmiyecekler demektir.

Maddenin idadesi okununca, eşyayı ve nakliye senedini tesellümden sonra doğan borçlar için, gönderenin, daha sonraki bir nakliyecinin borcundan dolayı daha önceki bir nakliyeciye de müracaat edebileceği zannı uyanmaktadır. Fakat Kanunumuz teselsülü bir kere daha bozmuştur. 918. inci maddeye göre: "nakliyeci aleyhine ikame olunacak tazminat davalari birinci ve sonuncu nakliyeci aleyhine ikame olunmak lâzımdur». Aradaki bir nakliyeci aleyhine dava açlabilmesi için her şeyden önce ziya veya hasarın o nakliyecinin naklettiği zaman içinde meydana geldiğinin de ispatı icap etmektedir.

Şu haIde Kanunumuzun kabul etmiş olduğu şekle göre karşlllklı ve tam teselsül, yani Borçlar Kanunumuzun 141. inci maddesinin anladı̆g mânada müteselsil borçluluk hali ancak birinci ve sonuncu nakliyeciler arasında vardır. Bunlar aynı zamanda aradaki nakliyccilerin bórçlarından da müteselsilen sorumludurlar. Aradaki nakliyecilere karşı dava açabilmek için zararın onlarm nakil ettikleri mesafede vukua geldiğinin ispat edilmesi lâzımdır.

\section{3. İ münasebet.}

Bundan sonra kanun nakliyecilerin sorumu bakımından iç münasebetlerine dair bazı hükümler koymuş, birbirlerine rücu imkânlarını tanzim etmiştir. Bir nakliyeci kendisinin sorumlu olmadiğı bir zarardan dolayı tazminat verirse kendisinden önceki nakJiyeciye veya asıl sorumlu olan nakliyeciye rücu edebilir. Zarardan nakliytcilerden hangisinin sorumlu olduğu tesbit olunamazsa, zarar bütün nakliyeciler arasında her birinin nakliye ücretindeki hissesi ilk mütenasip olmak üzere, taksim edilir. Zararın kendi mesafesinde doğmadığın ispat edebilen nakliyeci tazminat vermekten kurtulur.

\section{Zaman aşım?.}

Kanun koyucusu nakil-işlerindeki durumun bir ân önce aydın- 
lanmasımı, ihtilâfların uzayıp gitmemesini istediği için nakil sỏzleşmesinden doğan bütün hukuk davalarının bir senede zaman aşımına uğrıyacağını emretmiştir (TK. m. 889). Binaenaleyh bu gibi ihtilâflarda umumî zaman aşımı hakkındaki hükümler uygulanamaz (39).

Doçent Dr. Hikmet BELBEZ.

Bibliyoğrafya:

Şahap Arıç. Yargıtay içtihatlarına göre haşiyeli Ticaret Kanunu, İstanbul 1946. Konrad Cosack, Lehrbuck des Handelsrechts, 9. uncu basi.

Düringer - Hachenburrß - Bing, Handelsgeaetzbuch, Kommenter, 3. üncü bas1, 1932 , c. V2.

Julius von Gierke, Handelsrecht und Schiffahrtsrecht, 4 üncï bas1, 1933. Abdullah Pulat Gözübüyük, Sözleşmelerin fesih ve tadili bakımından Mücbir sebepler ve beklenmeyen haller. Ankara 1945.

Halsbury's Laws of England, 2. inci bast, c. 4 (Lord Hailsham).

E. Hirs, Ticaret Hukuku Dersleri, Istanbul 1946.

Lyon - Caên - Renautt, Traité de Droit Commercial, 4, inci basi. c. 3.

Mc Nait, The Law of the Air, 1932.

Oser - Schönenberber, Obligationenrecht, Kommentar zum Schweizerischen Zivilgestzbuch, 2.inci bası, c. V, 1.

Ritter, Kommentar zum Handelsgesetzbuch, 2.inci bas1, 1932.

Curt Rühland. Frachtgeschäfte, Rechtsvergleichendes Handwörterbuch für Zivil - und Handelsrecht, c. III, s. 520 vdd.

Shawcross - Beaumont, Air. Law, 1945.

Vasfi Raşit Sevig̈, Ticaret Kanunu Şerhi, C, 1, 1935.

Staub Kommentar zum Handelsgetzbuch, 12. inci ve 13. üncü basi.

Von Tuhr - Siegwart, Allgemeiner Teit des Schweizerischen Obligationęnrechts, 1944.

(39) YTDK. 2552 - 11.11.1940; 1202 - 17.5.1945; krş. Arıç, age,, No. 783,785. 